\title{
Effect of bovine somatotropin administration during induction of lactation in 15-month-old heifers on production and health
}

\author{
A. L. Macrina, ${ }^{1}$ A. C. W. Kauf, ${ }^{2}$ and R. S. Kensinger ${ }^{3}$ \\ Department of Dairy and Animal Science, The Pennsylvania State University, University Park 16802
}

\begin{abstract}
Lactation can be induced successfully in 15-mo-old dairy heifers. Treatment of heifers induced into lactation with bovine somatotropin (bST) during an established lactation improved milk production; however, milk yields were still variable. The objective of the present study was to evaluate whether starting bST treatment during induction of lactation, rather than after lactation was established, would improve milk production beyond that of heifers induced into lactation but not treated with bST. Healthy Holstein heifers ( $\mathrm{n}=32,15$ mo of age, $420 \pm 28 \mathrm{~kg}$ of body weight) were induced into lactation with subcutaneous injections of estradiol $(0.075 \mathrm{mg} / \mathrm{kg}$ of body weight per d) and progesterone $(0.25 \mathrm{mg} / \mathrm{kg}$ of body weight per d) for $7 \mathrm{~d}$. Bovine somatotropin $(500 \mathrm{mg}$ ) was administered to heifers (n $=16$ ) beginning on experimental d 1 along with the estrogen/progesterone treatment. Heifers continued to receive bST every $2 \mathrm{wk}$ for $10 \mathrm{wk}$. Control animals (n $=16$ ) received no bST during this time. Milking began on experimental d 18, and milk production was compared through $53 \mathrm{~d}$ in milk (experimental d 70). Mean daily milk yield was $36 \%$ higher for bST-treated heifers than for control animals. A $15.5 \%$ difference in milk production between the groups was sustained through 305 d of lactation, even after control animals began bST treatment at $54 \mathrm{~d}$ in milk. Milk fat percentage was similar in bST and control heifers. Milk protein percentage was lower in bST-treated heifers (3.58\%) compared with controls $(3.99 \%)$ during the treatment comparison period and for the remainder of lactation (bST $3.25 \%$, control $3.39 \%$ ). Heifers treated with bST produced more total milk fat and protein compared with controls during the treatment comparison period. Throughout the induced lactation, heifers gained 0.87 $\mathrm{kg} / \mathrm{d}$ and averaged 2.4 services/pregnancy; 30 became pregnant. Four heifers were culled during the induced
\end{abstract}

\footnotetext{
Received March 26, 2011

Accepted May 23, 2011.

${ }^{1}$ Corresponding author: ALM106@psu.edu

${ }^{2}$ Current location: Woodbury, PA.

${ }^{3}$ Current affiliation: Department of Animal Science, Oklahoma State University, Stillwater.
}

lactation, and 28 heifers calved at $27.6 \pm 2.0$ mo of age for a second lactation. Addition of bST to the lactation induction protocol was advantageous because it stimulated greater milk production.

Key words: induced lactation, dairy heifer, bovine somatotropin, mammary development

\section{INTRODUCTION}

Milk production in cows and heifers induced into lactation is highly variable and is less than that seen in postpartum animals (Smith and Schanbacher, 1974; Magliaro et al., 2004; Macrina et al., 2011). Clearly, the estrogen-progesterone treatment used to induce lactation does not mimic all of the changes associated with pregnancy and mammary gland development. A recent report (Macrina et al., 2011) found that inducing 15-mo-old heifers into lactation was not more profitable than traditional rearing methods with animals first calving at $25 \mathrm{mo}$ of age. An improved method to induce lactation might increase profitability, decrease variation among animals, or increase milk production compared with previous methods used.

Success rate of induced lactation varied from $60 \%$ (Smith and Schanbacher, 1973) to 100\% (Fulkerson, 1978). Smith and Schanbacher (1973) defined success as any animal that lactated. Fulkerson (1978) induced lactation in reproductively normal heifers at 22 to 32 mo of age and reported that all animals successfully lactated, producing greater than $5.6 \mathrm{~kg}$ milk per day at peak. However, they produced only 60 to $70 \%$ of that observed in primiparous postpartum lactations (Fulkerson, 1978). More recently, Macrina et al. (2011) reported a $97 \%$ success rate for inducing heifers into lactation, with the only nonresponder being an animal with a chronic bladder infection. Total milk production by heifers induced into lactation was $48 \%$ of that produced by primiparous cows in the same herd. However, the animals induced into lactation were much younger than the primiparous cows and would not have produced any milk under traditional management schemes (Macrina et al., 2011). Many of the earlier studies used animals with reproductive failure, which may have affected their ability to respond to the induced lactation protocol. 
In previous studies, peak milk production in induced lactations has ranged from approximately $7 \mathrm{~kg} / \mathrm{d}$ (Fulkerson, 1978) to over $20 \mathrm{~kg} / \mathrm{d}$ (Smith and Schanbacher, 1974). Macrina et al. (2011) observed a peak milk production range of 17 to $31 \mathrm{~kg} / \mathrm{d}$ and total lactation milk yield range of 1,633 to $8,418 \mathrm{~kg}$ for heifers induced into lactation at 15 mo of age. Inconsistent or no milk yield responses were observed following administration of dexamethasone (Peel et al., 1978), reserpine (Collier et al., 1977; Peel et al., 1978), placental lactogen (Byatt et al., 1997), or thyrotropin-releasing hormone (Jordan et al., 1981). In contrast, bST treatment has been shown to reliably increase milk production during induced lactation, both in cows (Magliaro et al., 2004) and in heifers (Macrina et al., 2011).

Heifers induced into lactation exhibited a gradual increase in milk yield and did not reach peak production until later in lactation compared with postpartum animals (Smith and Schanbacher, 1973; Kensinger et al., 1979; Fowler et al., 1991). Macrina et al. (2011) reported that heifers induced into lactation reached peak production at 175 DIM, later than the $125 \mathrm{~d}$ they had previously observed in mature cows induced into lactation (Magliaro et al., 2004). The increasing feed intake capacity due to overall body growth throughout lactation may have contributed to this longer time to reach peak production. In addition, mammary gland development may have continued for a longer period in heifers induced into lactation compared with mature cows induced into lactation and postpartum cows.

Bovine somatotropin administration beginning at 25 DIM to heifers induced into lactation at 15 mo of age resulted in a $14.7 \%$ increase in milk production compared with control animals (Macrina et al., 2011). This difference in milk production did not persist after all animals began receiving bST at 95 DIM. Thus, although mammary development may have continued during lactation for all heifers induced into lactation, it is unlikely that bST treatment caused additional proliferation of mammary epithelial cells during that period. In some studies (Stelwagen et al., 1992; Putnam et al., 1999), bST administered during late gestation resulted in increased milk production after parturition even when no bST was given after calving. This suggests that bST plays a role in mammogenesis before the onset of lactation. Treatment of cows or heifers with bST during lactation induction has the potential to increase mammary epithelial cell proliferation and subsequent milk production beyond levels observed when lactating animals are treated with bST. Therefore, the primary objective of the present study was to determine if implementation of bST treatment during induction of lactation would improve milk production above that of heifers induced into lactation but not treated with bST during the induction period.

\section{MATERIALS AND METHODS}

Fifteen-month-old, healthy Holstein heifers $(\mathrm{n}=32)$ were induced into lactation with estradiol and progesterone. Half of the heifers received bST as part of the induction protocol, whereas the other half served as controls. Heifers had a mean BW of $420 \pm 28 \mathrm{~kg}$ and mean BCS of $3.6 \pm 0.3$ at the onset of the experiment. Estrous cycles were synchronized using norgestomet ear implants with intramuscular injections of estradiol valerate and progesterone (Synchro-Mate-B, Sanofi Animal Health Inc., Overland Park, KS) so that all heifers would be in a similar phase of the cycle upon induction of lactation. They were induced in 4 groups with 8 heifers/group beginning of d $5 \pm 1$ of the estrous cycle. Heifers within each group were paired based on BW. Within each pair, heifers were assigned randomly to either bST or control treatment. In all other respects, pairs were managed identically during this portion of the experiment.

All heifers received daily subcutaneous injections of estradiol-17ß $(0.075 \mathrm{mg} / \mathrm{kg}$ of BW; E- 8875 , SigmaAldrich, St. Louis, MO) and progesterone $(0.25 \mathrm{mg} /$ $\mathrm{kg}$ of BW; P-0130, Sigma-Aldrich) for d 1 to 7 of the experiment. The hormone solution was prepared in absolute ethanol to achieve $15 \mathrm{mg} / \mathrm{mL}$ estradiol- $17 \beta$ and $50 \mathrm{mg} / \mathrm{mL}$ progesterone. Bovine somatotropin (500 mg; Posilac, Monsanto Co., St. Louis, MO) was administered to heifers in the bST treatment group (n $=16$ ) beginning on experimental d 1 along with the estrogen-progesterone treatment. They continued to receive bST every $2 \mathrm{wk}$ for $10 \mathrm{wk}$. Control animals $(\mathrm{n}=$ 16) were not treated with bST during this time. During the induction phase of the study, animals were housed in a climate-controlled barn in individual tie stalls to prevent injury due to estrous-like behavior associated with the estrogen-progesterone treatment.

Milking began on d 18 of the experiment and heifers were milked once per day until production reached approximately $3 \mathrm{~kg}$. They were then milked twice daily until their return to the Penn State University dairy herd at $17 \mathrm{~d}$ of lactation, after which they were milked 3 times per day until mid lactation $(\mathrm{d} 222 \pm 52)$ and then twice daily until dry off. Milk yield was measured daily, and milk samples were collected on lactation d 1, 7, 14, and 21 and monthly thereafter for the entire lactation. Samples were analyzed by DHIA on a 4400 Combi Foss analyzer (Foss, Hillerød, Denmark). Milk yield and milk composition differences due to bST were compared through 53 DIM. Four milk samples that were 
collected between $\mathrm{d} 7$ and 48 of lactation were used to determine effects of bST treatment on milk composition. Samples collected on d 1 of milking were not used in this analysis because they were colostrum-like and would not be representative of salable milk. Beginning on d 54 of lactation, all heifers received bST every 2 wk until 2 wk before dry off. Heifers were weighed monthly to monitor growth. In addition, reproduction and calving data were collected from herd records for each animal. Once the heifers entered the milking herd at d 17 of lactation, they were subjected to the same routine herd management protocols as all other cows in the Penn State University dairy herd. Heifers were eligible for breeding after a 50-d voluntary waiting period. Animals were dried off $60 \mathrm{~d}$ before expected calving or when milk production was less than $10 \mathrm{~kg} / \mathrm{d}$.

Before initiation of lactation, animals were fed a TMR designed to meet the NRC requirements of lategestation dairy cows (NRC, 1989). Two days before milking commenced (treatment d 16) heifers received a mixture containing equal parts of the dry cow TMR and a lactating cow TMR. Once milking began, animals received the lactating cow TMR ad libitum. They continued to receive the same lactating cow TMR in freestall housing upon their return to the Penn State University dairy herd. Diet ingredients presented (Table 1) are representative of those fed over the course of this research.

Data for response to bST, which included milk yield, milk composition, and BW, were analyzed using the Mixed procedure of SAS (version 9.1, SAS Institute, Cary, NC). For the bST versus control treatment comparison, the model included treatment, group, day of lactation or day of experiment, and first-order interactions. Subject was heifer (treatment $\times$ group), and lactation day was used as the repeated measure with an autoregressive type 1 covariance matrix. Number of services per heifer was also analyzed using Proc Mixed, and the model included treatment and group. Peak production was calculated using a 3-d rolling average. Day to peak production was the day with the highest $3-\mathrm{d}$ rolling average representing the previous day through the subsequent day. This experiment was approved by the Institutional Animal Care and Use Committee at the Pennsylvania State University.

\section{RESULTS}

Heifers that received bST as part of the lactation induction protocol produced $36 \%$ more milk than controls during the treatment period (Table 2). A treatment $\times$ time interaction $(P<0.05)$ was observed, indicating that the difference in milk production between bSTtreated heifers and controls increased over time (Figure
1). The higher production observed in the bST-treated animals was maintained throughout lactation even though controls were treated with bST starting on d 54 of lactation (Figure 2). Mean daily milk yield over the entire lactation until dry off averaged $21.6 \mathrm{~kg}$ for heifers that received bST during lactation induction and 18.7 $\mathrm{kg}$ for those that received bST starting on d 54 (Table 3; $P<0.01)$. Milk yields also were analyzed separately for d 54 to 305 to exclude the initial increase in production and compare the effect only when both groups received bST. Mean daily milk yields were higher for heifers that initially received bST $(22.6 \mathrm{~kg} / \mathrm{d})$ compared with those that did not $(19.9 \mathrm{~kg} / \mathrm{d} ; P<0.01)$.

Mean milk fat percentage averaged $4.1 \%$ for both bST-treated and control heifers (Table 2) and decreased from 4.2 to $3.8 \%$ over the course of the 53 -d comparison $(P<0.01)$. Milk protein content was approximately 0.4 percentage units lower in bST-treated heifers than in controls $(P<0.01$, Table 2$)$. A treatment $\times$ time interaction $(P<0.01)$ was observed; milk protein percentage decreased over time in both groups but the initial rate of decrease was faster in control heifers (Figure 3). Despite the lower milk protein percentage, the quantity of protein produced was higher for the bST-treated heifers $(P<0.01)$ because of their higher level of milk production (Table 2). Percentage lactose increased from 2.0 on d 1 to 5.1 on d 21 of lactation $(P$ $<0.01$ ); however, no differences were observed due to bST treatment. Lactose content was not measured in

Table 1. Diet composition and analyses for representative diets used

\begin{tabular}{|c|c|c|}
\hline Item & $\begin{array}{l}\text { Dry cow } \\
\text { TMR }\end{array}$ & $\begin{array}{l}\text { Lactating } \\
\text { cow TMR }\end{array}$ \\
\hline \multicolumn{3}{|l|}{ Ingredient, $\%$ of DM } \\
\hline Alfalfa hay, chopped & - & 8.9 \\
\hline Alfalfa hay silage & - & 16.5 \\
\hline Grass hay, chopped & 19.1 & - \\
\hline Grass hay silage & 20.9 & - \\
\hline Corn silage & 33.4 & 24.6 \\
\hline Ground corn & 17.2 & 18.4 \\
\hline Canola meal & - & 8.1 \\
\hline Soybeans, cooked & - & 2.8 \\
\hline Soybean meal, $48 \%$ & 5.6 & - \\
\hline Distillers grain & - & 7.4 \\
\hline Wheat middlings & - & 4.7 \\
\hline Soy hulls & - & 4.5 \\
\hline Tallow & - & 0.61 \\
\hline Dicalcium phosphate & - & 0.05 \\
\hline Calcium sulfate & 0.23 & - \\
\hline Salt & 0.23 & 0.45 \\
\hline Vitamin/mineral mix & 3.31 & 3.06 \\
\hline \multicolumn{3}{|l|}{ Composition } \\
\hline DM, \% & 42.4 & 52.5 \\
\hline $\mathrm{CP}, \%$ & 14.0 & 17.8 \\
\hline $\mathrm{ADF}, \%$ & 25.4 & 22.1 \\
\hline NDF, $\%$ & 41.8 & 35.5 \\
\hline $\mathrm{Ca}, \%$ & 0.62 & 0.90 \\
\hline $\mathrm{P}, \%$ & 0.34 & 0.46 \\
\hline $\mathrm{NE}_{\mathrm{L}}, \mathrm{Mcal} / \mathrm{kg}$ of DM & 0.68 & 0.76 \\
\hline
\end{tabular}


Table 2. Effect of bST on yield and composition of milk from heifers induced into lactation ${ }^{1}$

\begin{tabular}{lcccc}
\hline Component & bST & Control & SE & $P$-value \\
\hline Milk yield, kg/d & 15.1 & 11.1 & 0.43 & $<0.01$ \\
Fat, \% & 4.13 & 4.05 & 0.13 & NS \\
Fat, $\mathrm{kg} / \mathrm{d}$ & 0.54 & 0.38 & 0.02 & $<0.01$ \\
Protein, $\%$ & 3.58 & 3.99 & 0.08 & $<0.01$ \\
Protein, $\mathrm{kg} / \mathrm{d}$ & 0.46 & 0.36 & 0.02 & $<0.01$ \\
SCC $, \times 1,000$ cells $/ \mathrm{mL}$ & 278 & 323 & 94 & $\mathrm{NS}$ \\
\hline
\end{tabular}

${ }^{1}$ The bST versus control treatments were compared over the period from d 1 to 53 of lactation with 16 heifers per group. Milk production was measured daily, and a significant treatment $\times$ time interaction $(P<0.05)$ was observed. The comparison of milk composition between treatments was made after the heifers had made the transition from colostrum to mature milk and represents 4 samples per animal collected on d 7, 14, $21 \pm 0.4$, and $\mathrm{d} 37 \pm 11$ of lactation.

samples collected after d 21. No main effect of treatment on SCC was observed (Table 2), but a treatment $\times$ time interaction $(P<0.05)$ was found, with control animals having higher SCC on $\mathrm{d} 7$ and exhibiting a faster decline between d 7 and 14 compared with bSTtreated heifers. Early treatment with bST did not affect total lactation (through dry off, not 305-d corrected) milk fat yield, milk fat percentage, or protein yield compared with heifers that started bST after 53 DIM. However, milk protein percentage was lower for heifers that received bST treatment beginning at lactation induction compared with heifers that began bST treatment after 53 DIM. Heifers reached peak production of $25.6 \pm 5.3 \mathrm{~kg} / \mathrm{d}$ at $149 \pm 60$ DIM.

Induced heifers grew well during lactation and averaged $0.87 \mathrm{~kg}$ of BW gain per day. Early treatment with bST did not affect ADG during or subsequent to the treatment period. Thirty of the 32 animals induced into lactation became pregnant. Services per heifer averaged $2.4 \pm 0.4$ and did not differ between bST treatment groups. Twenty-eight heifers remained in the herd and calved at $27.6 \pm 2.0$ mo of age. Of the 4 heifers that were culled, 1 died in an accident (control, 193 DIM), 1 was culled for chronic mastitis (bST, 152 DIM), and 2 were culled for failure to conceive (bST, 416 DIM; control, 445 DIM). At the time of culling, all animals were receiving bST. The remaining animals stayed in the herd for 1 to 5 additional lactations (mean of $2.9 \pm$ 1.2 lactations).

\section{DISCUSSION}

Administration of bST to heifers at the onset of lactation induction and continuing through 53 DIM increased mean daily milk production by $36 \%$. This increase in production is greater than those observed in heifers (14.7\%) and cows (17.8\%) that received bST beginning at 25 DIM during an induced lactation (Magliaro et al., 2004; Macrina et al., 2011). The difference in milk yield between bST and control heifers

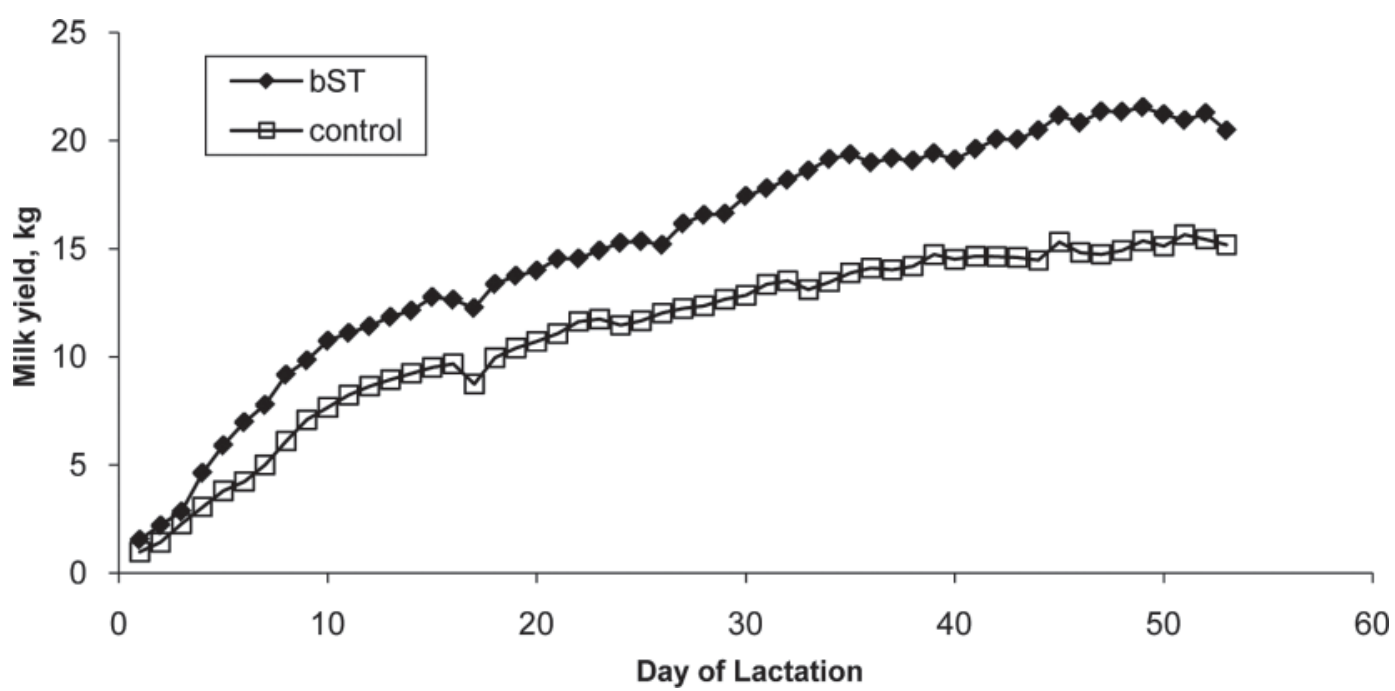

Figure 1. Milk yields of heifers induced into lactation and treated with bST ( ) versus not treated with bST (control; $\square$ ) during the induction process and early lactation. The 70-d bST treatment period started with the onset of lactation induction, which was $17 \mathrm{~d}$ before start of milking. Significant treatment $\times$ time interaction, $\mathrm{SE}=0.69, P<0.05$. 
Table 3. Effect of treatment with bST during lactation induction on full-lactation milk yield and milk component yield and percentage in heifers induced into lactation ${ }^{1}$

\begin{tabular}{|c|c|c|c|c|}
\hline Component & $\begin{array}{l}\text { bST during } \\
\text { induction }^{2}\end{array}$ & $\begin{array}{c}\text { no bST during } \\
\text { induction } \\
\left(_{\text {control })^{3}}\right.\end{array}$ & SE & $P$-value \\
\hline Milk yield, $\mathrm{kg} / \mathrm{d}$ & 21.6 & 18.7 & 0.66 & $<0.01$ \\
\hline Fat, $\%$ & 3.66 & 3.76 & 0.10 & NS \\
\hline Fat, kg & 236 & 201 & 22 & NS \\
\hline Protein, \% & 3.25 & 3.39 & 0.04 & $<0.05$ \\
\hline Protein, kg & 211 & 180 & 19 & NS \\
\hline DIM & 306 & 288 & 21 & NS \\
\hline
\end{tabular}

${ }^{1}$ Milk production was measured daily and milk composition was measured monthly. Values represent milk production and composition for the entire lactation until dry off and are not 305-d corrected.

${ }^{2} \mathrm{Administration}$ of bST began during induction of lactation ( $17 \mathrm{~d}$ before onset of milking) and continued every 2 wk for the remainder of lactation $(\mathrm{n}=16)$.

${ }^{3}$ Control heifers received no bST during induction of lactation. Beginning on d 54 of lactation, they were treated with bST every $2 \mathrm{wk}$ for the remainder of lactation.

in the present study was evident $(P<0.01)$ by $\mathrm{d} 4$ of lactation. Ewes induced into lactation and treated with bST during the induction period produced $98 \%$ more milk than induced ewes that did not receive bST (Ramirez Andrade et al., 2008). Ewes treated with bST during late gestation produced more milk than ewes treated with saline (Stelwagen et al., 1993). Prepartum treatment of cows with bST failed to increase milk production in some studies (Bachman et al., 1992; Simmons et al., 1994; Eppard et al., 1996) but did increase milk yields in others (Putnam et al., 1999; Gulay et al., 2003, 2004). Many possible reasons exist to explain the differences in response to prepartum treatment with bST. Bachman et al. (1992) may have not observed a response to bST because their animals did not exhibit an increase in IGF-I concentrations following bST treatment, so other factors, such as inadequate nutrition, might have prevented a milk yield response (Bauman, 1999). Simmons et al. (1994) administered $14 \mathrm{mg} / \mathrm{d}$ of bST, which is considerably lower than the

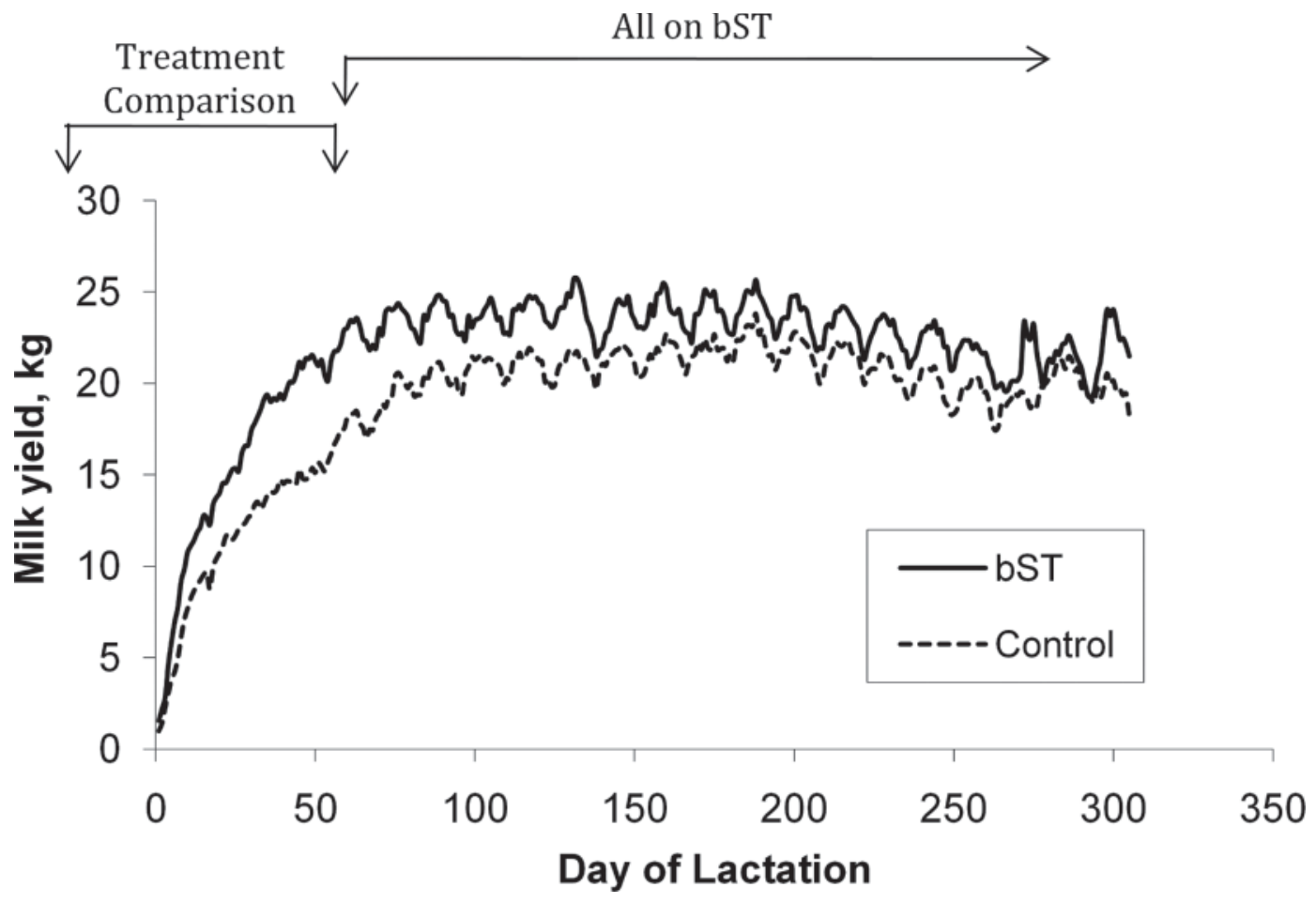

Figure 2. Lactation milk yields of heifers induced into lactation and treated with bST (-) versus not treated with bST (control; - - -) during the induction process and early lactation. The 70-d bST/control treatment comparison period started with the onset of lactation induction, which was $17 \mathrm{~d}$ before start of milking. Beginning on d 54 of lactation, all heifers were treated with bST every 2 wk for the remainder of lactation. Significant effect of bST, $\mathrm{SE}=0.66, P<0.01$. 


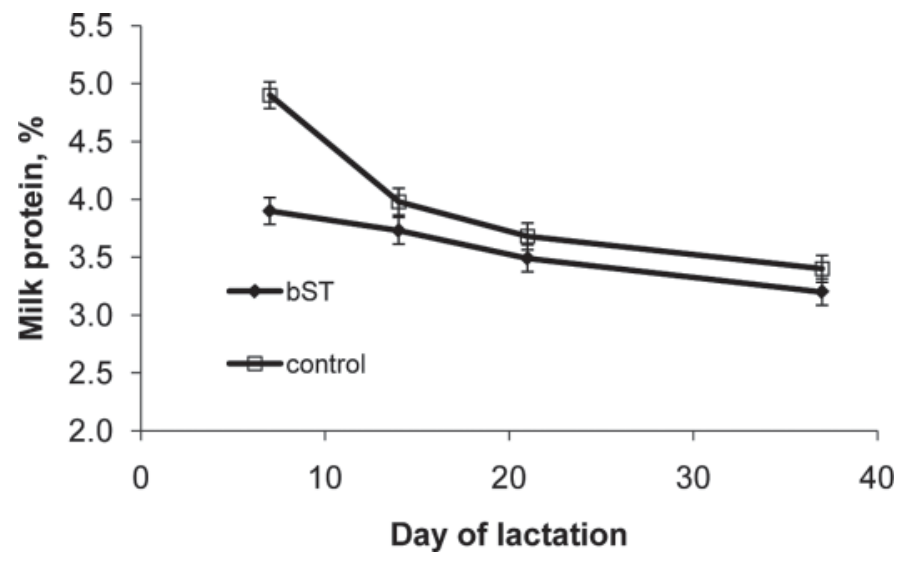

Figure 3. Milk protein percentages of heifers induced into lactation and treated with bST $(\bullet)$ versus not treated with bST (control; $\square$ ) during the induction process and early lactation. The 70-d bST treatment period started with the onset of lactation induction, which was $17 \mathrm{~d}$ before start of milking. The bST versus control treatments were compared over the period from d 1 to 53 of lactation with 16 heifers per group. Milk samples were collected on d 7, d 14, d $21 \pm 0.4$, and d $37 \pm 11$ of lactation. Effect of treatment with bST, SE $=0.08, P<$ 0.01. Treatment $\times$ time interaction, $\mathrm{SE}=0.12, P<0.01$.

dose used in the present study (500 mg over $14 \mathrm{~d}$ ). Stelwagen et al. (1992) injected heifers with bST during the last trimester of gestation and observed a $19 \%$ increase in milk production. However, this increase was not apparent until after $90 \mathrm{~d}$ of lactation. Gulay et al. (2003, 2004) continued bST treatment into early lactation, and Putnam et al. (1999) administered bST up to 3 times before parturition, with the third injection occurring, on average, $4 \mathrm{~d}$ before calving. Elevated plasma concentrations of somatotropin due to continued administration of bST (Gulay et al., 2003, 2004) or a carry-over effect from injections shortly before calving (Putnam et al., 1999) could explain the increases in production observed in these studies. Studies have shown a galactopoietic effect of exogenous bST during early lactation (Richard et al., 1985; Stanisiewski et al., 1992), although the magnitude of increased milk production is less that that observed later in lactation (Richard et al., 1985).

The increase we observed in milk production due to bST could be the result of a greater number of mammary epithelial cells, a greater proportion of differentiated cells, or an increased secretory activity per cell. It is not clear whether mammogenesis in the cow continues during lactation. Akers et al. (1981) reported that mammary epithelial cell numbers increased in the period between $10 \mathrm{~d}$ before and $10 \mathrm{~d}$ after calving. Whether this increase occurred before, after, or both before and after parturition is not known. Relative rates of cell proliferation and apoptosis have indicated that very little mammary growth occurred after d 14 of lactation (Capuco et al., 2001). Exogenous bST administration increased plasma IGF-1 in late pregnancy and early lactation (Vicini et al., 1991), and IGF-1 has been shown to stimulate DNA synthesis in mammary cells cultured from both pregnant and lactating cows (Baumrucker and Stemberger, 1989). Somatotropin increased synthesis and secretion of $\alpha$-casein in bovine mammary epithelial cells in vitro (Sakamoto et al., 2005). However, it is not known if this would occur or to what extent it would occur in vivo. Some studies (Knight et al., 1992; Capuco et al., 2001) showed a possible mammogenic effect of bST, whereas others (Capuco et al., 1989; Binelli et al., 1995) found no effect. These studies were conducted with lactating cows or mammary tissue from lactating cows, and it appears that relatively little mammogenesis occurs during lactation in the cow with or without bST treatment. Treatment with bST during the time when the mammary gland is highly proliferative may produce different results. Also, heifers induced into lactation follow a different time course for mammary development and milking compared with pregnant animals. Perhaps these animals continue significant mammary development well into lactation.

Other factors could affect mammary development in response to bST. Limited feed consumption decreased the proportion of proliferating mammary cells (Capuco et al., 2001), and the authors hypothesized that bST increased mammary cellular proliferation but the proliferation might have been blunted by reduced energy balance. Heifers in the present study did not appear to experience reduced or negative energy balance as evidenced by their growth rates, and therefore, they may have possessed greater capacity for mammary cell proliferation compared with postpartum cows in early lactation.

Pubertal heifers treated with bST showed increased mammary parenchyma compared with controls (Sejrsen et al., 1986). However, no histological or cytological differences were observed in the parenchyma between control and bST treatments; the amount of parenchyma was simply greater in the bST group. Prepubertal heifers treated with bST have increased mammary epithelial cell proliferation compared with controls (Berry et al., 2003). The fact that milk production was higher in heifers treated with bST compared with controls and that the increase was sustained even after controls began receiving bST at 54 DIM, suggests that bST treatment during lactation induction increased the number of mammary epithelial cells or alternatively, a greater proportion was differentiated. Ewes treated with bST during late gestation showed an increase in mammary parenchymal cell number but not an increase in cellular activity, indicating that increased mammogenesis was responsible for the increased milk production observed (Stelwagen et al., 1993). Whether this occurred in 
heifers in the present study is unknown; however, we speculate that they had a greater number of mammary epithelial cells compared with controls.

The relatively slow change in milk composition compared with that in postpartum cows was expected and has been observed previously. This reflects the lactation-induced animal's slower increase in milk production at the onset of lactation compared with cows that have calved (Smith and Schanbacher, 1973; Kensinger et al., 1979; Macrina et al., 2011). Heifers induced into lactation in the present study had greater whole-lactation milk fat and protein percentages compared with those measured in postcalving lactations as reported by Erb et al. (1976), Davis et al. (1983), and Macrina et al. (2011). In the present study, treatment with bST did not affect milk fat percentage; however, treatment resulted in a lower milk protein percentage compared with heifers not treated with bST. Despite this, heifers that received bST produced more total protein compared with controls. Treatment with bST has not been shown to affect milk composition in postpartum cows in positive energy balance (Bauman, 1992) or in cows and heifers induced into lactation (Magliaro et al., 2004; Macrina et al., 2011). The heifers in the present study, however, had higher milk production than those induced into lactation previously (Macrina et al., 2011), and they continued to grow well, averaging 0.87 $\mathrm{kg}$ of BW gain per day over the course of the study. In a study on growth of Holstein heifers in the United States, Heinrichs and Losinger (1998) reported mean BW of 409.3 and $528.9 \mathrm{~kg}$ at 15.5 and $23.5 \mathrm{mo}$ of age, respectively, resulting in an ADG of $0.49 \mathrm{~kg}$. Heinrichs (1993) stated that Holstein heifers should calve at a BW of 560 to $600 \mathrm{~kg}$, and that this could be achieved with a prepubertal ADG of $0.65 \mathrm{~kg}$ and a postpubertal ADG of $0.85 \mathrm{~kg}$. The induced-lactation heifers in the present study continued to grow at an appropriate rate even during lactation. In addition, the bST-treated heifers did not produce milk protein at the expense of their own growth rate. Perhaps these animals had reached a limit of protein deposition into milk and body tissue with priority given to body tissue. The present study is unique in that it is the first to report a decrease in milk protein percentage due to bST treatment. The large increase in milk production may serve to increase potential profitability of induced lactation. At the present time, induced lactation is not approved by the FDA for commercial use. However, it provides a mechanism to study mammary gland development independent of pregnancy and parturition.

Overall, heifers induced into lactation in the present study were healthy. Approximately $94 \%$ of the animals were diagnosed as pregnant, and $88 \%$ remained in the herd and calved. It took longer for heifers in the present study to reach peak milk production compared with postpartum animals, but this appears typical for induced lactations in dairy cattle (Magliaro et al., 2004; Macrina et al., 2011). The 4 animals culled during the induced lactation represented a $12.5 \%$ culling rate, which is low compared with the average US culling rates of $24 \%$ for postpartum cows (NAHMS, 2007) but similar to the $14 \%$ of primiparous cows culled before completing their first lactations (Heins et al., 2006). Heifers in the present study had approximately 3 lactations before culling, which is similar to that previously reported for heifers induced into lactation (Macrina et al., 2011) and similar to the mean of 2.8 lactations for Holsteins in the United States (Hare et al., 2006). The estradiol-progesterone-bST induction protocol has the potential to increase profitability of induced lactation over that observed when bST is not included in the induction protocol (Macrina et al., 2011).

\section{CONCLUSIONS}

Our results from the present study and a previous study (Macrina et al., 2011) indicate that the response to bST in heifers induced into lactation differs depending on whether the bST is administered at the start of lactation induction or after lactation is already established. During early lactation, before 54 DIM, heifers that received bST during lactation induction had a mean daily milk yield $36 \%$ higher than that of control animals. This increased production is much higher than the increases of 12 to $15 \%$ typically associated with bST administration. The increased milk production observed was sustained throughout lactation even after control heifers were treated with bST. It is likely that heifers treated with bST during the induction phase had more mammary secretory tissue compared with controls. Addition of bST to the lactation induction protocol was advantageous because it resulted in higher milk production.

\section{ACKNOWLEDGMENTS}

This work was supported by Hatch funds and by USDA special grant no. 96-34281-3028 to R. S. Kensinger. The authors thank Dawn Sanzotti, Robyn Graboski, Steve Blackburn, Mark Amsler, Virginia Ishler, Nadine Houck, and other colleagues at the Penn State Dairy Research and Education Center (University Park, PA) for their contributions.

\section{REFERENCES}

Akers, R. M., D. E. Bauman, A. V. Capuco, G. T. Goodman, and H. A. Tucker. 1981. Prolactin regulation of milk secretion and biochemical differentiation of mammary epithelial cells in periparturient cows. Endocrinology 109:23-30. 
Bachman, K. C., D. H. Wilfond, H. H. Head, C. J. Wilcox, and M. Singh. 1992. Milk yields and hormone concentrations of Holstein cows in response to sometribove (somatotropin) treatment during the dry period. J. Dairy Sci. 75:1883-1890.

Bauman, D. E. 1992. Bovine somatotropin: Review of an emerging animal technology. J. Dairy Sci. 75:3432-3451.

Bauman, D. E. 1999. Bovine somatotropin and lactation: From basic science to commercial application. Domest. Anim. Endocrinol. 17:101-116.

Baumrucker, C. R., and B. H. Stemberger. 1989. Insulin and insulinlike growth factor-I stimulate DNA synthesis in bovine mammary tissue in vitro. J. Anim. Sci. 67:3503-3514.

Berry, S. D., P. M. Jobst, S. E. Ellis, R. D. Howard, A. V. Capuco, and R. M. Akers. 2003. Mammary epithelial proliferation and estrogen receptor alpha expression in prepubertal heifers: Effects of ovariectomy and growth hormone. J. Dairy Sci. 86:2098-2105.

Binelli, M., W. K. Vanderkooi, L. T. Chapin, M. J. Vandehaar, J. D. Turner, W. M. Moseley, and H. A. Tucker. 1995. Comparison of growth hormone-releasing factor and somatotropin: Body growth and lactation of primiparous cows. J. Dairy Sci. 78:2129-2139.

Byatt, J. C., R. H. Sorbet, P. J. Eppard, T. L. Curran, D. F. Curran, and R. J. Collier. 1997. The effect of recombinant bovine placental lactogen on induced lactation in dairy heifers. J. Dairy Sci. 80:496-503.

Capuco, A. V., J. E. Keys, and J. J. Smith. 1989. Somatotropin increases thyroxine-5'-monodeiodinase activity in lactating mammary tissue of the cow. J. Endocrinol. 121:205-211.

Capuco, A. V., D. L. Wood, R. Baldwin, K. McLeod, and M. J. Paape. 2001. Mammary cell number, proliferation, and apoptosis during a bovine lactation: Relation to milk production and effect of bST. J. Dairy Sci. 84:2177-2187.

Collier, R. J., D. E. Bauman, and R. L. Hays. 1977. Effect of reserpine on milk production and serum prolactin of cows hormonally induced into lactation. J. Dairy Sci. 60:896-901.

Davis, S. R., R. A. Welch, M. G. Pearce, and A. J. Peterson. 1983. Induction of lactation in nonpregnant cows by estradiol-17 beta and progesterone from an intravaginal sponge. J. Dairy Sci. 66:450-457.

Eppard, P. J., J. J. Veenhuizen, W. J. Cole, P. G. Comens-Keller, G. F. Hartnell, R. L. Hintz, L. Munyakazi, P. K. Olsson, R. H. Sorbet, T. C. White, C. A. Baile, R. J. Collier, J. P. Goff, and R. L. Horst. 1996. Effect of bovine somatotropin administered to periparturient dairy cows on the incidence of metabolic disease. J. Dairy Sci. 79:2170-2181.

Erb, R. E., E. L. Monk, T. A. Mollett, P. V. Malven, and C. J. Callahan. 1976. Estrogen, progesterone, prolactin and other changes associated with bovine lactation induced with estradiol-17 $\beta$ and progesterone. J. Anim. Sci. 42:644-654.

Fowler, P. A., C. H. Knight, and M. A. Foster. 1991. In vivo magnetic resonance imaging studies of mammogenesis in non-pregnant goats treated with exogenous steroids. J. Dairy Res. 58:151-157.

Fulkerson, W. J. 1978. Artificial induction of lactation: A comparative study in heifers. Aust. J. Biol. Sci. 31:65-71.

Gulay, M. S., M. J. Hayen, M. Liboni, T. I. Belloso, C. J. Wilcox, and H. H. Head. 2004. Low doses of bovine somatotropin during the transition period and early lactation improves milk yield, efficiency of production, and other physiological responses of Holstein cows. J. Dairy Sci. 87:948-960.

Gulay, M. S., M. J. Hayen, L. C. Teixeira, C. J. Wilcox, and H. H. Head. 2003. Responses of Holstein cows to a low dose of somatotropin (bST) prepartum and postpartum. J. Dairy Sci. 86:31953205 .

Hare, E., H. D. Norman, and J. R. Wright. 2006. Survival rates and productive herd life of dairy cattle in the United States. J. Dairy Sci. 89:3713-3720.

Heinrichs, A. J. 1993. Raising dairy replacements to meet the needs of the 21st century. J. Dairy Sci. 76:3179-3187.

Heinrichs, A. J., and W. C. Losinger. 1998. Growth of Holstein dairy heifers in the United States. J. Anim. Sci. 76:1254-1260.

Heins, B. J., L. B. Hansen, and A. J. Seykora. 2006. Fertility and survival of pure Holsteins versus crossbreds of Holstein with
Normande, Montbeliarde, and Scandinavian Red. J. Dairy Sci. 89:4944-4951.

Jordan, D. L., R. E. Erb, P. V. Malven, C. J. Callahan, and E. L. Veenhuizen. 1981. Artificial induction of lactation in cattle: Effect of modified treatments on milk yield, fertility, and hormones in blood plasma and milk. Theriogenology 16:315-329.

Kensinger, R. S., D. E. Bauman, and R. J. Collier. 1979. Season and treatment effects on serum prolactin and milk yield during induced lactation. J. Dairy Sci. 62:1880-1888.

Knight, C. H., J. E. Hillerton, M. A. Kerr, R. M. Teverson, A. Turvey, and C. J. Wilde. 1992. Separate and additive stimulation of bovine milk yield by the local and systemic galactopoietic stimuli of frequent milking and growth hormone. J. Dairy Res. 59:243-252.

Macrina, A. L., R. S. Kensinger, and P. R. Tozer. 2011. Induced lactation in pubertal heifers: Efficacy, response to bovine somatotropin and profitability. J. Dairy Sci. 94:1355-1364.

Magliaro, A. L., R. S. Kensinger, S. A. Ford, M. L. O'Connor, L. D. Muller, and R. Graboski. 2004. Induced lactation in nonpregnant cows: Profitability and response to bovine somatotropin. J. Dairy Sci. 87:3290-3297.

NAHMS. 2007. Part I: Reference of Dairy Cattle Health and Management Practices in the United States. USDA, Washington, DC.

NRC. 1989. Nutrient Requirements of Dairy Cattle. 6th rev. ed. Natl. Acad. Sci., Washington, DC.

Peel, C. J., J. W. Taylor, I. B. Robinson, A. A. McGowan, R. D. Hooley, and J. K. Findlay. 1978. The importance of prolactin and the milking stimulus in the artificial induction of lactation in cows. Aust. J. Biol. Sci. 31:187-195.

Putnam, D. E., G. A. Varga, and H. M. Dann. 1999. Metabolic and production responses to dietary protein and exogenous somatotropin in late gestation dairy cows. J. Dairy Sci. 82:982-995.

Ramirez Andrade, B., A. A. Salama, G. Caja, V. Castillo, E. Albanell and X. Such. 2008. Response to lactation induction differs by season of year and breed of dairy ewes. J. Dairy Sci. 91:2299-2306.

Richard, A. L., S. N. McCutcheon, and D. E. Bauman. 1985. Responses of dairy cows to exogenous bovine growth hormone administered during early lactation. J. Dairy Sci. 68:2385-2389.

Sakamoto, K., T. Komatsu, T. Kobayashi, M. T. Rose, H. Aso, A. Hagino, and Y. Obara. 2005. Growth hormone acts on the synthesis and secretion of alpha-casein in bovine mammary epithelial cells. J. Dairy Res. 72:264-270.

Sejrsen, K., J. Foldager, M. T. Sorensen, R. M. Akers, and D. E. Bauman. 1986. Effect of exogenous bovine somatotropin on pubertal mammary development in heifers. J. Dairy Sci. 69:1528-1535.

Simmons, C. R., W. G. Bergen, M. J. Vandehaar, D. J. Sprecher, C. J. Sniffen, E. P. Stanisiewski, and H. A. Tucker. 1994. Protein and fat metabolism in cows given somavubove before parturition. J. Dairy Sci. 77:1835-1847.

Smith, K. L., and F. L. Schanbacher. 1973. Hormone induced lactation in the bovine. I. Lactational performance following injections of 17ß-estradiol and progesterone. J. Dairy Sci. 56:738-743.

Smith, K. L., and F. L. Schanbacher. 1974. Hormone induced lactation in the bovine. II. Response of nulligravida heifers to modified estrogen-progesterone treatment. J. Dairy Sci. 57:296-303.

Stanisiewski, E. P., L. F. Krabill, and J. W. Lauderdale. 1992. Milk yield, health, and reproduction of dairy cows given somatotropin (Somavubove) beginning early postpartum. J. Dairy Sci. 75:2149-2164.

Stelwagen, K., D. G. Grieve, B. W. McBride, and J. D. Rehman. 1992. Growth and subsequent lactation in primigravid Holstein heifers after prepartum bovine somatotropin treatment. J. Dairy Sci. $75: 463-471$.

Stelwagen, K., D. G. Grieve, J. S. Walton, J. L. Ball, and B. W. McBride. 1993. Effect of prepartum bovine somatotropin in primigravid ewes on mammogenesis, milk production, and hormone concentrations. J. Dairy Sci. 76:992-1001.

Vicini, J. L., F. C. Buonomo, J. J. Veenhuizen, M. A. Miller, D. R. Clemmons, and R. J. Collier. 1991. Nutrient balance and stage of lactation affect responses of insulin, insulin-like growth factors I and II, and insulin-like growth factor-binding protein 2 to somatotropin administration in dairy cows. J. Nutr. 121:1656-1664. 